\title{
COMMUNITY VULNERABILITY LEVELS IN THE COASTAL AREA OF PARIAMAN BEACH IN FACING EARTHQUAKE DISASTERS
}

\author{
Muhammad Alfi ${ }^{1}$, Edwar $^{2}$, Zairin $^{3}$, Warsa Sugandi ${ }^{4}$, Suhendro ${ }^{5}$ \\ ${ }^{1,2,3,4}$ Geography Education, Universitas Prof. Dr. Hazairin, $\mathrm{SH}$ \\ ${ }^{5}$ Geography Education, Universitas Pendidikan Indonesia \\ E-mail: Muhammadalfi299@gmail.com
}

\begin{abstract}
This study aims to obtain data, process, analyze and discuss the Community Vulnerability in the Coastal Areas of Pariaman City in Earthquake Disaster Mitigation. This type of research is descriptive qualitative. The population in this study are villages along the coast of Pariaman. Total population of 1117 households (KK). Sampling of respondents based on Proposional Random Sampling, namely $10 \%$ of the total population, so that the respondents totaled 117 people. Data collection techniques using questionnaires and interviews. Descriptive qualitative data analysis used frequency and percentage tables. The results of this study indicate the level of community vulnerability in the coastal area of Pariaman in earthquake mitigation shows a high vulnerability category. The general public must always be given outreach on a regular basis to be able to understand about knowledge before a disaster, during a disaster and after a disaster.
\end{abstract}

Keywords: Vulnerability; Earthquake Disaster; Mitigation

\section{A. INTRODUCTION}

Indonesia is geographically located in an area prone to natural disasters. Geographically, Indonesia is at the confluence of three active plates in the world, namely the Eurasian, IndoAustralian and Pacific plates (BNPB, 2015). This resulted in a large number of volcanic and tectonic activities, some of which resulted in subsequent disasters such as tsunamis. (LIPI-UNESCO/ISDR, 2006) Identified the most frequent disasters in Indonesia such as floods, droughts, forest and land fires, hurricanes, earthquakes, tsunamis, volcanic eruptions, technology, technological failures, and epidemic disasters (Maryani \& Yani, 2001).

(Aydan, 2008) States that Indonesia has experienced thousands of earthquakes and hundreds of tsunamis in the last four earthquakes in a hundred years. In Indonesia as a whole, no sea coast in Indonesia is safe from tsunamis except the west coast of Kalimantan and the east coast of Sumatra (Muhari, Diposaptono, \& Imamura, 2007).

The pattern of development and activity centers which are mostly located in coastal areas causes the level of vulnerability to disasters to be very high in the majority of regions in Indonesia. The 
potential hazards of this natural disaster are large-scale accompanied by the vulnerability of social conditions, infrastructure, economy, policies, and local bureaucracy as an effect of their complexity and rapid growth (Chikoto, Sadiq, \& Fordyce, 2013). This resulted in the largest number of coastal districts in tsunami prone areas which often neglected aspects of natural disaster mitigation in their development.

West Sumatra Province is located on the west coast of the island of Sumatra, which has historically been well known as a disaster-prone area, especially earthquakes (Alfi, Darsiharjo, \& Maryani, 2019). This vulnerability is inversely proportional to the community's low vulnerability in the face of an earthquake. Meanwhile, the domination of population activities is mostly centered in coastal areas (Danny Hilman Natawidjaja, 2007). The earthquake hazard that threatens the province of West Sumatra is triggered by the presence of a megathurst zone (subduction zone) in the Mentawai (McCloskey et al., 2008).

On September 30, 2009 an earthquake measuring 7.9 on the Richter scale occurred in southwest Pariaman. The result is a very dire impact on all sectors of the economy, transportation, government, health, education and communication. (Spittal, McClure, Siegert, \& Walkey,
2008) States that the damage to community facilities and infrastructure includes: 9,432 units of public buildings, 442 government offices, 4,748 educational buildings, 153 health buildings, 68 bridges and 2,851 places of worship. All access and public facilities were paralyzed after the big earthquake hit.

There are several sectors that experienced a large loss impact, including the infrastructure sector which suffered a loss of up to Rp. 963 billion, the social sector 1.52 trillion, the economic sector Rp. 2.3 trillion, and cross-sector (the government and environment sub-sector) experienced a loss of 674,6 billion, so that the total loss value was recorded at $\mathrm{Rp}$. 20.86 trillion (Spittal et al., 2008).

The suffering caused by the disaster was the loss of life and the destruction of the physical environment including houses and public facilities which had an impact on economic and social losses (BNPB, 2017). This disaster caused 1,179 casualties in all cities and districts in West Sumatra, 1,214 people were seriously injured and 1,688 people were slightly injured (McCloskey et al., 2008).

This incident became a valuable lesson for the people of West Sumatra, especially Pariaman. This is because Pariaman is one of the areas that suffered severe damage and the highest number of victims. The public must always be 
vigilant because we cannot predict natural events, what we can do is try to minimize the damage that will occur with these events.

In order to know the risks that are around, it is necessary to know the hazards, vulnerabilities and capacities that exist in the community (Röbke \& Vött, 2017). States that vulnerability is a condition that is determined by physical, social, economic and environmental factors or processes that result in a decreased ability to face hazards (Rahmi \& Satria, 2013). Explains that the level of vulnerability is a concept in which a certain community group does not or lacks the capacity and ability to respond to a crisis / conflict situation (emergency response) (Rahmi \& Satria, 2013).

There are three factors that influence this condition. First, socio-culture and human resources in facing the crisis, the second is economic aspects related to poverty levels, access to basic food, and types of work, and the third aspect of infrastructure and housing (Bullock, Haddow, \& Coppola, 2013). The relationship between community vulnerability to natural disasters has been widely discussed and studied by a number of researchers including (Twigg, Greig, \& Lanka, 2001), (Mileti, 1999), (Cutter, Boruff, \& Shirley, 2003), (Cardona, 2005), and (Wisner, Blaikie, Cannon, \&
Davis, 2003), who Among other things, emphasizing the need to conduct a community vulnerability assessment in the micro scope to determine the level of risk it will face.

Who published the BBC framework for vulnerability assessment linked disaster risk reduction to efforts to build community capacity (Amri, Bird, Ronan, Haynes, \& Towers, 2017). Community capacity building can be carried out through various activities, including: 1) dissemination of disaster impacts and hazards; 2) education to the public regarding disaster hazards; and 3) disaster mitigation carried out by related parties. The main hope is to reduce the impact of disasters on society in both material and non-material forms (Carley, Malik, Landwehr, Pfeffer, \& Kowalchuck, 2016).

Then the final goal is to foster a culture and awareness of disasters in the midst of the Pariaman community so that they are always able to face various possibilities during disasters. This encourages researchers to conduct research that aims to determine the level of vulnerability of coastal communities in the city of Pariaman in the face of earthquakes.

\section{B. MATERIALS AND METHODS}

The method used in this study is a survey research method with a qualitative 
approach. (Kankam, 2020 in Creswell) defines qualitative research as "an approach for exploring and understanding the meaning individuals or groups ascribe to a social or human problem".

Qualitative research enables researchers "to conduct in-depth studies about a broad array of topics" (Kankam, 2020). Argues that survey research is research that takes a sample from one population and uses questionnaires and tests as the main data collection tools (Singarimbun, 2007).

This research was conducted for 1 month, from 28 November to 28 December 2018. The research locations were in Kota Pariaman, namely Pasir Sunur Village, Marunggi Village and Manggung Village. The population in this study were all people living along the coast of Kota Pariaman as many as 1,117 people. The research sample was taken by proportional random sampling with a proportion of $10 \%$ so that the sample totaled 117 people.

The data in this study were obtained by means of a questionnaire. The data obtained in the field were then analyzed using the scoring method, namely by scoring each of the assessed vulnerability parameters and then describing each result. The analysis technique used in this study is a percentage to determine the level of vulnerability of the community in the coastal area of Pariaman in the face of an earthquake.

\section{RESULTS AND DISCUSSION}

The results of research data in this study, there are several factors that indicate the level of community vulnerability, including factors of education, genre, age, marital status, livelihood, economy, socio-culture, infrastructure, and preparedness which are packaged in the following figure.

\section{Educational Factors Affecting Vulnerability Levels}

Based on the results of the research on the variable level of vulnerability, there are 3 categories according to (LIPIUNESCO/ISDR, 2006) with each score, namely: low vulnerability (54-44), moderate vulnerability (43-33) and high vulnerability (32-22). Based on these categories, the results in Table 1.

Table 1. Education Affects Vulnerability Level

\begin{tabular}{clcc}
\hline No & $\begin{array}{c}\text { Vulnerability } \\
\text { Level }\end{array}$ & $\begin{array}{c}\text { Frequency } \\
(f)\end{array}$ & $\begin{array}{c}\text { Percentage } \\
(\%)\end{array}$ \\
\hline 1 & Low & 39 & 33.3 \\
\hline 2 & Moderate & 58 & 49.6 \\
\hline 3 & High & 20 & 17.1 \\
\hline & Amount & 117 & 100 \\
\hline
\end{tabular}

Source: Primary Data Processing, 2018

Table 1 shows that education affects the level of vulnerability of society after analyzing the results of the measurement can be categorized as moderate with respondents who answered as many as 58 
people $(49.6 \%)$. For more details, see Figure 1.

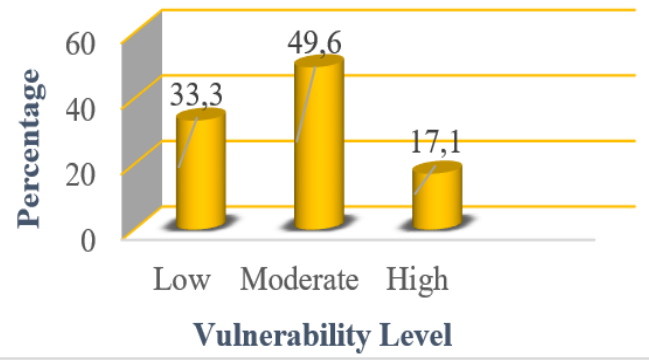

Figure 1. Education Influences Vulnerability Level

Source: Primary Data Processing (2018)

\section{Genre Factors Affecting Vulnerability} Levels

The vulnerability of society in terms of genre can be seen in Table 2 .

Table 2. Genre Affects Vulnerability Level

\begin{tabular}{clcc}
\hline \multirow{2}{*}{ No } & $\begin{array}{c}\text { Vulnerability } \\
\text { Level }\end{array}$ & $\begin{array}{c}\text { Frequency } \\
(f)\end{array}$ & $\begin{array}{c}\text { Percentage } \\
(\%)\end{array}$ \\
\hline 1 & Low & 17 & 14.5 \\
\hline 2 & Moderate & 33 & 28.2 \\
\hline 3 & High & 67 & 57.3 \\
\hline & Amount & 117 & 100 \\
\hline
\end{tabular}

Source: Primary Data Processing, 2018

Table 2. Shows that the factors of different genres affect the level of vulnerability of society. After analyzing the measurement results can be categorized as high with respondents who answered as many as 67 people (57.3\%). For more details, see Figure 2.

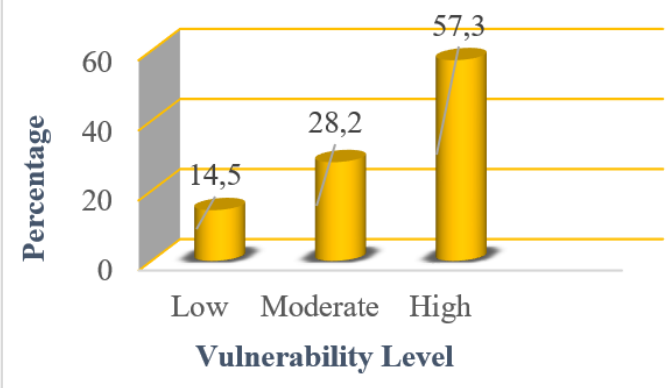

Figure 2. Genre Affects Vulnerability Level

Source: Primary Data Processing (2018)
Age Factors Affect Vulnerability Level The vulnerability of the community in terms of age can be seen in Table 3 .

Table 3. Age Affects Vulnerability Level

\begin{tabular}{clcc}
\hline \multirow{2}{*}{ No } & $\begin{array}{c}\text { Vulnerability } \\
\text { Level }\end{array}$ & $\begin{array}{c}\text { Frequency } \\
(f)\end{array}$ & $\begin{array}{c}\text { Percentage } \\
(\%)\end{array}$ \\
\hline 1 & Low & 15 & 12.8 \\
\hline 2 & Moderate & 27 & 23.1 \\
\hline 3 & High & 75 & 64.1 \\
\hline & Amount & 117 & 100 \\
\hline
\end{tabular}

Source: Primary Data Processing, 2018

Table 3. Shows that the age factor affects the level of community vulnerability. After analyzing the measurement results can be categorized as high with respondents who answered as many as 75 people (64.1\%). For more details, see Figure 3.

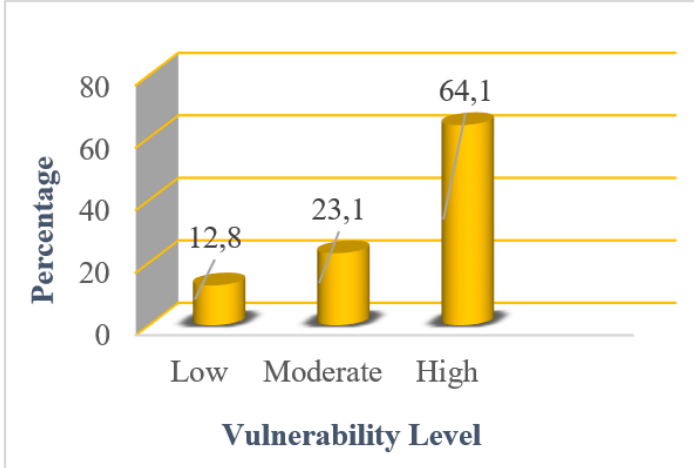

Figure 3. Age Affects Vulnerability Source: Primary Data Processing (2018)

\section{Marital Status Factors Affecting Vulnerability Levels}

The vulnerability of the community seen from their marital status can be seen in Table 4.

Table 4. Marital Status Affects Vulnerability Level

\begin{tabular}{clcc}
\hline No & $\begin{array}{c}\text { Vulnerability } \\
\text { Level }\end{array}$ & $\begin{array}{c}\text { Frequency } \\
(f)\end{array}$ & $\begin{array}{c}\text { Percentage } \\
(\%)\end{array}$ \\
\hline 1 & Low & 26 & 22.2 \\
\hline 2 & Moderate & 34 & 29.0 \\
\hline 3 & High & 57 & 48.8 \\
\hline & Amount & 117 & 100 \\
\hline
\end{tabular}

Source: Primary Data Processing, 2018

Table 4. Shows that the factor of marital status affects the level of 
vulnerability of society. After analyzing the measurement results can be categorized as high with respondents who answered as many as 57 people $(48.8 \%)$. For more details, see Figure 4.

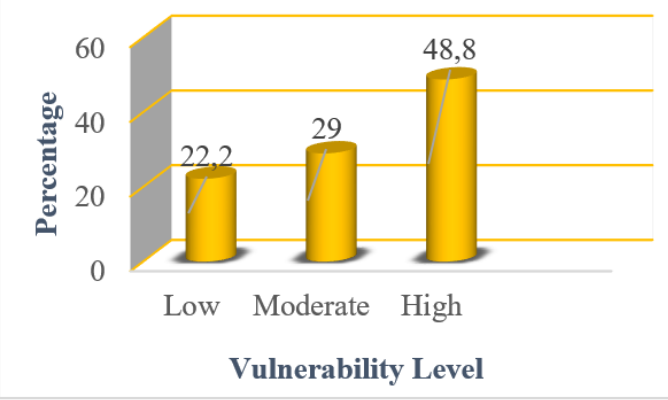

Figure 4. Marital Status Affects Vulnerability Level

Source: Primary Data Processing (2018)

\section{Livelihood Factors Affecting Vulnerability Levels}

Community vulnerability in terms of livelihood can be seen in Table 5 .

Table 5. Livelihoods Affect Vulnerability Levels

\begin{tabular}{cccc}
\hline No & $\begin{array}{c}\text { Vulnerability } \\
\text { Level }\end{array}$ & $\begin{array}{c}\text { Frequency } \\
(f)\end{array}$ & $\begin{array}{c}\text { Percentage } \\
(\%)\end{array}$ \\
\hline 1 & Low & 16 & 13.7 \\
\hline 2 & Moderate & 24 & 20.5 \\
\hline 3 & High & 77 & 65.8 \\
\hline & Amount & 117 & 100 \\
\hline
\end{tabular}

Source: Primary Data Processing, 2018

Table 5. Shows that livelihood factors influence the level of vulnerability of the community. After analyzing the measurement results can be categorized as high with respondents who answered as many as 77 people (65.8\%). For more details, see Figure 5.

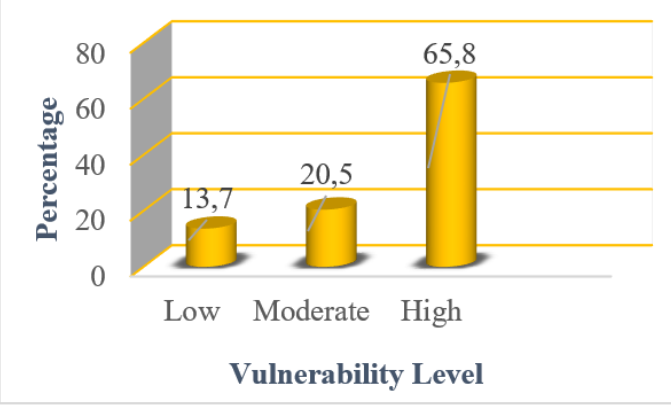

Figure 5. Livelihoods Affect Vulnerability Level

Source: Primary Data Processing (2018)

\section{Economic Factors Affecting the Level of} Vulnerability

The vulnerability of society seen from economic factors can be seen in Table 6 .

Table 6. Economic Influence Vulnerability Level

\begin{tabular}{clcc}
\hline No & $\begin{array}{c}\text { Vulnerability } \\
\text { Level }\end{array}$ & $\begin{array}{c}\text { Frequency } \\
(f)\end{array}$ & $\begin{array}{c}\text { Percentage } \\
(\%)\end{array}$ \\
\hline 1 & Low & 13 & 11.1 \\
\hline 2 & Moderate & 20 & 17.1 \\
\hline 3 & High & 84 & 71.8 \\
\hline & Amount & 117 & 100 \\
\hline
\end{tabular}

Source: Primary Data Processing, 2018

Table 6. Shows economic factors affecting the level of community vulnerability. After analyzing the measurement results can be categorized as high with respondents who answered as many as 84 people $(71.8 \%)$. For more details, see Figure 6.

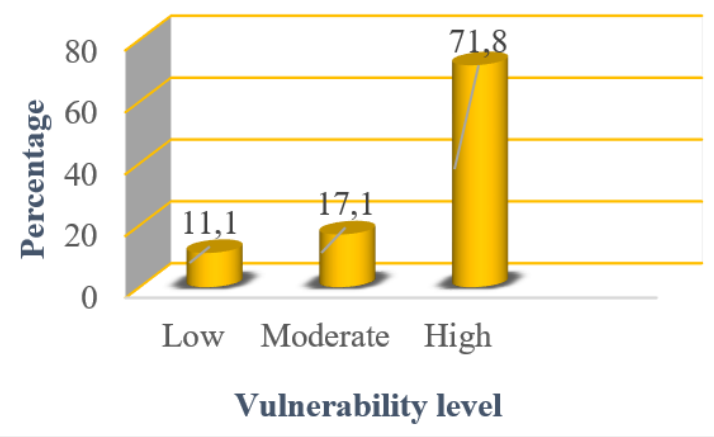

Figure 6. Economy Affects Vulnerability Level

Source: Primary Data Processing (2018)

\section{Socio-Cultural Factors Affecting Vulnerability Levels}

Community vulnerability seen from the socio-culture can be seen in Table 7 . 
Table 7. Socio-Culture Affects Vulnerability Levels

\begin{tabular}{clcc}
\hline No & $\begin{array}{c}\text { Vulnerability } \\
\text { Level }\end{array}$ & $\begin{array}{c}\text { Frequency } \\
(f)\end{array}$ & $\begin{array}{c}\text { Percentage } \\
(\%)\end{array}$ \\
\hline 1 & Low & 37 & 31.6 \\
\hline 2 & Moderate & 50 & 42.7 \\
\hline 3 & High & 30 & 25.7 \\
\hline & Amount & 117 & 100 \\
\hline
\end{tabular}

Source: Primary Data Processing, 2018

Table 7. Shows the socio-cultural factors affecting the level of vulnerability of the community. After being analyzed the measurement results can be categorized as moderate with respondents who answered as many as 50 people $(42.7 \%)$. For more details, see Figure 7.

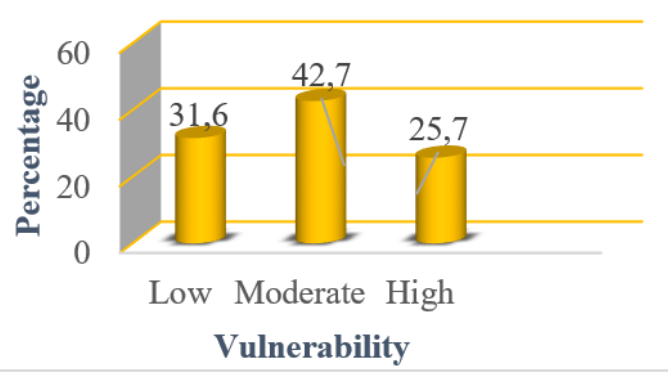

Figure 7. Socio-Cultural Influencing Vulnerability Level

Source: Primary Data Processing (2018)

\section{Infrastructure Factors Affecting Vulnerability Levels}

The vulnerability of the community in terms of infrastructure can be seen in Table 8.

Table 8. Infrastructure Affects Vulnerability Levels

\begin{tabular}{clcc}
\hline No & $\begin{array}{c}\text { Vulnerability } \\
\text { Level }\end{array}$ & $\begin{array}{c}\text { Frequency } \\
(f)\end{array}$ & $\begin{array}{c}\text { Percentage } \\
(\%)\end{array}$ \\
\hline 1 & Low & 24 & 20.5 \\
\hline 2 & Moderate & 63 & 53.8 \\
\hline 3 & High & 30 & 25.7 \\
\hline & Amount & 117 & 100 \\
\hline
\end{tabular}

Source: Primary Data Processing, 2018

Table 8. Shows that infrastructure factors influence the level of vulnerability of the community. After analyzing the measurement results can be categorized as moderate with respondents who answered as many as 63 people (53.8\%). For more details, see Figure 8.

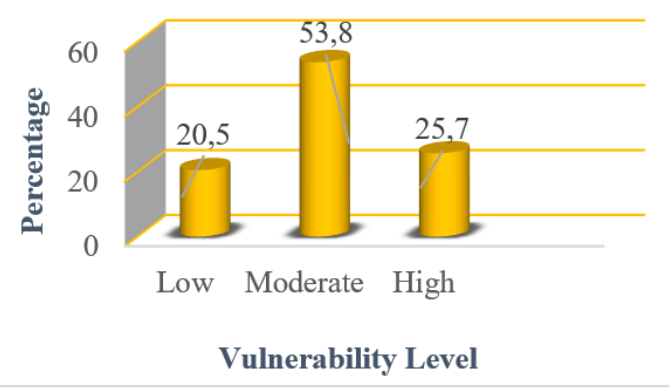

Figure 8. Influencing Infrastructure Vulnerability Level

Source: Primary Data Processing (2018)

\section{Preparedness Factors Affecting} Vulnerability Levels

Community vulnerability seen from preparedness can be seen in Table 9 .

Table 9. Preparedness Affects Vulnerability Levels

\begin{tabular}{clcc}
\hline No & $\begin{array}{c}\text { Vulnerability } \\
\text { Level }\end{array}$ & $\begin{array}{c}\text { Frequency } \\
(f)\end{array}$ & $\begin{array}{c}\text { Percentage } \\
(\%)\end{array}$ \\
\hline 1 & Low & 22 & 18.8 \\
\hline 2 & Moderate & 31 & 26.5 \\
\hline 3 & High & 64 & 54.7 \\
\hline & Amount & 117 & 100 \\
\hline
\end{tabular}

Source: Primary Data Processing, 2018

Table 9. Shows the preparedness factors affecting the level of community vulnerability. After being analyzed the measurement results can be categorized as moderate with respondents who answered as many as 64 people $(54.7 \%)$. For more details, see Figure 9.

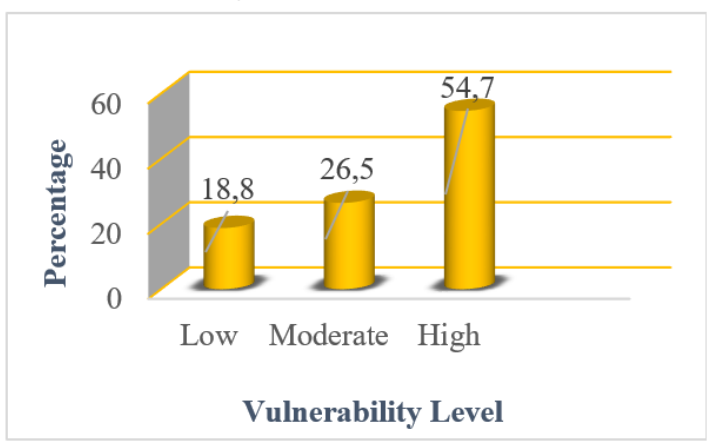

Figure 9. Preparedness Affects Vulnerability Levels Source: Primary Data Processing (2018) 
D. CONCLUSIONS

The average percentage of respondents' answers regarding the level of vulnerability of communities in coastal areas of Pariaman in facing disasters shows a high level of vulnerability. The high level of vulnerability in the community can be classified into 3 , namely: a) social and cultural; b) economy and c) infrastructure.

The results in the field show that the level of community vulnerability in the coastal area of Pariaman in the face of earthquake disasters in terms of education factors with moderate levels of vulnerability (49.6\%), genre factors with high levels of vulnerability (57.3\%), age factors with high levels of vulnerability $(64.1 \%)$, marital status factors with a high level of vulnerability (48.8\%), livelihood factors with a high level of vulnerability (65.8\%), economic factors with a high level of vulnerability $(71.8 \%)$, sociocultural factors with a moderate level of vulnerability (42.7\%), infrastructure factors with a moderate level of vulnerability (53.8\%), and a preparedness factor with a moderate level of vulnerability (54.7\%).

There are several things that can be done to minimize the vulnerability of the community in the face of earthquake disasters, including the government through related agencies providing education and socialization on strategies to improve preparedness. Socialization and education regarding this preparedness strategy were provided continuously and then formed in each disaster preparedness group village as a pioneer in the community. This socialization and education material covers conditions before a disaster, during a disaster and after a disaster. The goal is to form a calm metal and psyche when faced with disasters and this is expected to reduce vulnerability in dealing with disasters.

Based on the results of the research that has been done, the results of this study are expected to become material for information and reference in adopting policies by the Pariaman government regarding the vulnerability of society in the face of earthquake disasters and become one of the materials for further research in the future.

\section{E. REFERENCES}

Alfi, M., Darsiharjo, \& Maryani, E. (2019). Development of Natural Disaster Mitigation Teaching Materials to Improve Understanding of Disasters. Journal of Physics: Conference Series, 1387(1). https://doi.org/10.1088/17426596/1387/1/012079

Amri, A., Bird, D. K., Ronan, K., Haynes, K., \& Towers, B. (2017). Disaster risk reduction education in Indonesia: Challenges and recommendations for scaling up. 
Natural Hazards and Earth System Sciences, 17(4), 595-612. https://doi.org/10.5194/nhess-17595-2017

Aydan, O. (2008). Aydan2008.Pdf.

Baru, A. (2007). Masri Singarimbun dan Sofyan Effendi, Metode Penelitian Survey , LP3ES , Manajemen , 2001-2002.

BNPB. (2015). Definisi dan Jenis Bencana. Badan Nasional Penanggulangan Bencana, 2-5. https://doi.org/10.1016/j.cell.2007.0 5.058

BNPB. (2017). Latihan Kesiapsiagaan Bencana, 145.

Bullock, J. A., Haddow, G. D., \& Coppola, D. P. (2013). Mitigation, Prevention, and Preparedness. Homeland Security, 237-268. https://doi.org/10.1016/B978-0-12415803-0.00010-6

Cardona, O. D. (2005). A system of indicators for disaster risk management in the Americas. Measuring Vulnerability to Natural Hazards: $\quad$ Towards Disaster Resilient Societies, 189-209.

Carley, K. M., Malik, M., Landwehr, P. M., Pfeffer, J., \& Kowalchuck, M. (2016). Crowd sourcing disaster management: The complex nature of Twitter usage in Padang Indonesia. Safety Science, 90, 4861.https://doi.org/10.1016/j.ssci.201 6.04 .002

Chikoto, G. L., Sadiq, A. A., \& Fordyce, E. (2013). Disaster Mitigation and Preparedness: Comparison of Nonprofit, Public, and Private Organizations. Nonprofit and Voluntary Sector Quarterly, 42(2), 391-410. https://doi.org/10.1177/0899764012 452042

Cutter, S. L., Boruff, B. J., \& Shirley, W.
L. (2003). Social vulnerability to environmental hazards. Social Science Quarterly, 84(2), 242-261. https://doi.org/10.1111/15406237.8402002

Danny Hilman Natawidjaja. (2007). Gempabumi dan Tsunami di Sumatra dan Upaya Untuk Mengembangkan Lingkungan Hidup. Gempa Bumi, 13(December), 66.

Kankam, P. K. (2020). Approaches in Information Research. New Review of Academic Librarianship, 26(1), 165-183.

https://doi.org/10.1080/13614533.2 019.1632216

LIPI-UNESCO/ISDR. (2006). Kajian Kesiapsiagaan Masyarakat dalam Mengantisipasi Bencana Gempabumi dan Tsunami, 579. Retrieved from http://www.bukue.lipi.go.id/utama.c gi?lihatarsip\&jans001\&1273262299 $\& 51$

Maryani, E., \& Yani, A. (2001). Kearifan Lokal Masyarakat Sunda Dalam Memitigasi Bencana Dan Aplikasinya Sebagai Sumber Pembelajaran Ips Berbasis Nilai. In Jurnal Penelitian Pendidikan (Vol. 14). Retrieved from http://ejournal.upi.edu/index.php/JE R/article/view/3111/2132

McCloskey, J., Antonioli, A., Piatanesi, A., Sieh, K., Steacy, S., Nalbant, S., ... Dunlop, P. (2008). Tsunami threat in the Indian Ocean from a future megathrust earthquake west of Sumatra. Earth and Planetary Science Letters, 265(1-2), 6181.https://doi.org/10.1016/j.epsl.200 7.09.034

Mileti, D. (1999). Disasters by Design. Disasters by Design. https://doi.org/10.17226/5782

MUHARI, A., DIPOSAPTONO, S., \& 
IMAMURA, F. (2007). Toward an Integrated Tsunami Disaster Mitigation: Lessons Learned from Previous Tsunami Events in Indonesia. Journal of Natural Disaster Science, 29(1), 13-19. https://doi.org/10.2328/jnds.29.13

Rahmi, Y., \& Satria, A. (2013). Correlation Analysis beetwen the Level of Vulnerability of Coastal Communities with Efforts of Disaster Risk Reduction. Penyuluhan, 9(2), 185-199.

Röbke, B. R., \& Vött, A. (2017). The tsunami phenomenon. Progress in Oceanography, 159(September), 296-322.

https://doi.org/10.1016/j.pocean.201 7.09.003

Spittal, M. J., McClure, J., Siegert, R. J., \& Walkey, F. H. (2008). Predictors of two types of earthquake preparation: Survival activities and mitigation activities. Environment and Behavior, 40(6), 798-817. https://doi.org/10.1177/0013916507 309864

Twigg, J., Greig, B., \& Lanka, S. (2001). Sustainable Livelihoods and Vulnerability. Management, (March), $10-11$. https://doi.org/10.13140/RG.2.2.204 36.42889

Wisner, B., Blaikie, P., Cannon, T., \& Davis, I. (2003). At Risk: natural hazards, people's vulnerability and disasters Second edition The attached three chapters constitute Part I of the book, and have been made available in the public domain by the authors and Routledge as part of the UNDP follow up to $t$. Framework, 134. 